\title{
Is the INTERNET CHANGING OUR CONCEPTION OF Democracy? AN AnALYSIS OF THE INTERNET USE During Protests and its Efect on the Perception OF DEMOCRACY
}

Javier Sajuria (j.sajuria@ucl.ac.uk)

Department of Political Science University College London.

The last several years have seen the rise of social movements around the globe, such as the student protests in the UK and Chile, the Arab Spring, the Indignados, and the Occupy movement. They represent different political aspirations, but all of them relied heavily on the Internet to communicate and organise. This research analyses two specific contentious processes - the UK student protests and the Chilean environmentalist protests in 2010 - to assess the effect that the Internet may have had on the protesters' perception of democracy. Through data gathered from online surveys, interviews, and the Oxford Internet Survey 2009, this article observes the effect of the Internet in two dimensions: support for democracy, and the protesters' conception of democracy. Preliminary results show that Internet use is related to a more horizontal conception of democracy, and that more analyses are required to test whether that association is caused by the Internet or a utopian discourse about it.

Keyword: democracy, Internet, protests, Chile, UK.

\section{¿ESTÁ INTERNET CAMBIANDO NUESTRA CONCEPCIÓN DE LA DEMOCRACIA? UN ANÁLISIS DEL USO DE INTERNET DURANTE PROTESTAS Y SU EFECTO EN LA PERCEPCIÓN DE LA DEMOCRACIA}

El último tiempo hemos visto el surgimiento de movimientos sociales alrededor del globo, tales como las protestas estudiantiles en Chile y el Reino Unido, la Primavera Árabe, los Indignados y el movimiento Ocupa. Todos ellos representan distintas aspiraciones políticas, pero coinciden en el uso intensivo de internet para comunicarse y organizarse. Esta investigación analiza el caso de las protestas estudiantiles en el Reino Unido en 2010 y las protestas medioambientales en Chile del mismo año para evaluar el posible efecto que internet tiene en la percepción sobre la democracia que tienen quienes protestan. Usando datos obtenidos de encuestas online, entrevistas y la Oxford Internet Survey de 2009, este artículo se enfoca en el efecto de internet en el apoyo a la democracia y la concepción que tienen de ella los manifestantes. Los resultados preliminares sugieren que el uso de internet está relacionado con una concepción más horizontal de la democracia, pero se requieren análisis posteriores para determinar si esa asociación es causada por internet, o por un discurso utópico sobre la tecnología.

Palabras clave: democracia, internet, protestas, Chile, Reino Unido. 
On November 11th, 2010, over 50,000 ${ }^{1}$ demonstrators walked through the streets of London, protesting against the plans of the recently elected coalition government to raise the cap on university fees. However, the protest did not only take place on the streets. Thousands of messages on Twitter and Facebook were sent during that day and the national demonstrations that followed on November 24th and December 9th. Earlier that year, in Chile, thousands of activists and protesters had flooded the streets of Santiago asking the government to halt the construction of a coal-fire power plant in the locality of Punta de Choros, 2 a Chilean nature reserve. The protests appeared as a spontaneous uprising co-ordinated over Twitter and Facebook. In 2011, another protest against the construction of a power plant arose. This time it was in response to the Hidroaysén project, which would consist of a series of dams in the Pascua and Baker rivers in Chilean Patagonia. Again, the Internet was a fertile ground for communication and organisation among the demonstrators.

Both cases - Chile and the UK - may seem like isolated examples of protests around the world; but both also reflect a new way of political mobilisation to which the Internet is pivotal, that has been under investigation for the last few years (Cantijoch, 2008; Garret, 2006; Norris, Walgrave, \& Van Aelst, 2005; Tarrow, 2008; Van Laer, 2007; Van Laer \& Van Aelst, 2009). The use of the Internet in the context of protest is still a young research area, and as such, there are several questions yet to be answered.

This article intends to delve deeper into the relationship between the use of the Internet during a protest, and the citizens' views about democracy. This relationship can refer to the level of support for the democratic system, or, in a deeper sense, to the way that democracy is conceived (Dalton, Shin, \& Jou, 2008). Online platforms allow the production and transmission of information in a completely different way than had hitherto been the case, and this has also affected the ways that protests are undertaken (Van Laer \& Van Aelst, 2009). The remaining question is to discover how the same platforms - used during a protest period - may affect the way that democracy is perceived.

\section{Perception of Democracy: Why is it Relevant?}

According to Diamond (2008), one of the main indicators of the level of legitimacy in a democratic system, is the level of citizen's support for it. In that sense, surveys have attempted to observe the level of support for democracy, especially in countries with

The Guardian, November 11, 2010.

2 La Nación, August 26, 2010. 
authoritarian regimes or in processes of transition to democracy. Strictly speaking, there are two particular dimensions that allow an understanding to be gleaned of how people view democracy, and how they connect it with their own realities.

The first dimension refers to the idea that people from a given country are able to support democracy as a system of government, regardless of their evaluation of their own governments (Diamond, Shin and Jou 2008). There is a common belief that support for democracy tends to be higher in countries with several years of democratic rule. Nevertheless, as Dalton, Shin and Jou (2008) shows, public opinion endorses democracy in the most unlikely places. Even countries under authoritarian rule or just starting a transition from it to a more democratic system tend to have high levels of support for democracy.

The levels of support for democracy, then, may follow an "axiological rationality" model (Sarsfield \& Echegaray, 2006), in which it relies on people's beliefs about it, and not in its outcomes. The importance of this idea is that the legitimacy of a democratic system may not be at risk even if the democratic government is not able to deliver the expected outcomes.

The second dimension is what people understand when they speak about democracy. A significant number of people understand democracy in terms of the freedom and liberties that democracy is supposed to bring (Dalton, Shin and Jou, 2008). A second group is composed of people who relate democracy to institutional arrangements and procedures, such as elections and the existence of a parliament. A third and smaller group thinks about democracy in terms of social rights.

Although this classification is useful to understanding the different views of democracy, some scholars contest it. Welzel and Ingelhart (2008), for example, distinguish between "electoral democracy" - which is mainly driven by elites and "liberal democracy", which requires a mass voice and wider participation opportunities. For them, the key to what people search for, and understand when they speak about democracy is more related to an "effective democracy", that is, a system that facilitates citizen empowerment. Electoral democracy, as it is only concentrated on periodical and limited demonstrations of citizen power - e.g. elections - cannot cope with it. In that regard, the empowerment required for an effective democracy comes from the existence of democratic institutions that enable people to develop values of self-expression. Their views of democracy, then, not only relate to liberties, institutions or civil rights, but also to notions of a more equal and horizontal society. The underlying idea is that democracy is no 
longer understood as a limited and narrow concept - i.e., elections - but rather as a "process by which political power moves into the hands of ordinary citizens" (Welzel \& Inglehart, 2008:29).

These two dimensions of the perception of democracy are essential to solving the legitimacy dilemma. Moreover, the way that people understand democracy may affect the way they choose to exercise their participation rights, which may in turn be affected by the tools they use to exercise them. When people believe that democracy is the only desirable system of government, and relate it to the idea of citizen empowerment, they may decide to use collective action to fill any gap between their expectations of democracy and what the democratic system is actually providing them with.

\section{The Internet and Contentious Politics}

The term 'contentious politics' is derived from the notion of confrontation. It is not only a process of regular political confrontation between elites, but also involves ordinary people who decide to organise and face their government or authorities. As Tarrow (2008:7) explains,

"(C)ollective action becomes contentious when it is used by people who lack regular access to representative institutions, who act in the name of new or unaccepted claims, and behave in ways that fundamentally challenge others or authorities".

The idea is that those who engage in this type of collective action find themselves with the opportunities, structures and resources needed to act in that way (McAdam, Tarrow \& Tilly, 2001). Those structures refer to the presence of social networks that allow the operation of collective action. When a continuous sequence of contentious events sustained by the presence of social networks can be observed, it could be ascribed to the presence of social movements. Moreover, protests are just one of the different options contained in a repertoire of contentious action (Tilly \& Tarrow, 2007) and, as such, are becoming mainstream. Demonstrations take place in different countries with different systems of government, and cannot be considered as something apart from the more usual mechanisms of political action, such as electoral politics (Tarrow, 2008).

When talking about the Internet, there is the subject of significant academic differences between the so-called 'utopians' and 'dystopians'. On the one hand, it can be observed that the Internet will lower the transaction costs of engaging in collective action. In that sense, the Internet would enhance the participation rates of 
those excluded or underrepresented (Cantijoch, 2008; Van Laer \& Van Aelst, 2009). On the other hand, others claim that the Internet will only reinforce the positions of those already involved in the political process. This may create a change in the effects of their protests, but will not give the "under-represented" a new tool of participation (Cantijoch, 2008). Finally, there is a group of sceptics who believe that the Internet will not change anything in the political process (Morozov, 2011; Van Laer, 2007). According to this view, the Internet will follow a similar path to that of TV or other technological inventions. There will be a big buzz about its political possibilities but, in the end, it will not affect the way that politics is conducted, in this case the way that people mount protests as a form of political participation.

The evidence from different social movements of the last few years (Bennett, Breunig, \& Givens, 2008; Cantijoch, 2008; Di Gennaro \& Dutton, 2006; Garret, 2006; Van Laer, 2007) tends to support the reinforcement theory. That is, the socioeconomic profile and levels of political awareness of those who use the Internet to engage in protests tend to be the same as those who do not use it.Additionally, some researchers (Van Laer \& Van Aelst, 2009) have found that the use of the Internet during protests may enhance a notion of political participation as a less hierarchical activity. As Cantijoch (2008) explains, Internet users are more satisfied with democracy and less supportive of the idea of hierarchical citizenship. The evidence gathered by Bennett, Breuning and Givens (2008) supports this idea by claiming that there has been a shift in the collective action paradigm. For them, the Internet sustains looser networks that are more related to the idea of horizontality in the political process. If the Internet is fostering a more horizontal approach to political action, it may also influence the way that Internet-supplemented protesters understand democracy.

The role of the Internet must not be overestimated, though. Almost all of the scholarship on the topic agrees on the importance of face-to-face contacts to activate and sustain networks of collective action. Nonetheless, the use of the Internet may affect people's understanding of politics and, consequently, of democracy. 


\section{Data and Measurements}

\section{Case selection}

Both the UK and Chilean occurrences of contentious politics present an interesting challenge. Both series' of events were took place during a similar period of time and had very similar processes of development. As some of the interviewees explained, both sequences of demonstrations developed from previous planning and organisation. In the UK, once the government announced its plans to raise the cap on university fees, the National Union of Students (NUS) decided to start planning a national demonstration against the policy. Alongside more traditional ways of organisation and communication, such as posters and leaflets, the NUS created Facebook groups, Twitter accounts and an official website for the first demonstration. ${ }^{3}$

In the Chilean case, the protests against both of the power plants required meticulous planning of the actions undertaken. In the case of Punta de Choros, a group of activists created a documentary and decided to offer free screenings of it in different parts of the country. A website ${ }^{4}$ and Facebook campaign were created with videos of popular Chilean artists supporting the initiative. In the case of Hidroaysén, there was another big organisation called "Patagonia sin represas" ${ }^{5}$ which had been campaigning against the project for several years before the protests. It was not until the government had to decide on whether or not to approve of construction that the demonstrations started to take place.

There are other important similarities between both cases. In Chile and the UK, there were new conservative governments, which had been elected after long periods of more left-wing rule. Also, in both cases the Internet played a key role before and during the protests. Nevertheless, both cases also present differences that enrich the analysis. The UK has a long tradition of democratic rule and participates in most of the groups of developed countries. Chile, on the other hand, suffered a military dictatorship between 1973 and 1990, and has been conducting a peaceful and institutional process of transition since then. Only in 2010 was Chile granted admission to the OECD. In terms of public opinion about democracy, the UK has followed a stable pattern since the first barometer surveys, while in Chile there have

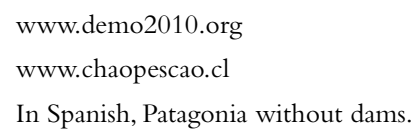


been several changes in people's perception about democracy (Lagos, 2008). With respect to the Internet, both countries have different levels of penetration $-82 \%$ in the UK and $54.8 \%$ in Chile ${ }^{6}$ - but they are way ahead of the world average of $30.2 \%$. Interestingly, the penetration of Facebook follows the opposite pattern: in the UK, $58 \%$ of Internet users had a Facebook profile whereas in Chile, 92\% of the users do ${ }^{6}$.

The idea behind this particular case selection is, as Yin (2008:61) explains, to avoid the "uniqueness or artifactual conditions surrounding the case" - as in a single case approach - in accounting for most of the findings of the investigation. Furthermore, following Gerring's $(2004,2007)$ approach, the idea is to combine a cross-sectional analysis across two different units that have some similarities but which also present variation in their contexts. Chile and the UK experienced similar dynamics of contention, which can be analysed together, considering their own particularities (McAdam et al., 2001).

\section{Data}

The data was gathered using methodological triangulation between surveys and interviews. Thirteen semi-structured interviews were conducted in Chile and the UK. The interviewees belonged to three different groups: media, activists and academics. All of the interviews were conducted with the promise of anonymity, and as such, no names are disclosed in this investigation. The idea of this was to provide a safer environment for the interviewees to express their views on the topic. In the media group, reporters from the BBC and The Guardian (in the case of the UK) and La Tercera and El Dínamo (in Chile) were interviewed. All of them were members of the editorial staff of their media organisations or were directly involved in the coverage of the protests. Top officers from student unions, the NUS and Greenpeace Chile, as well as activists from the UCL occupation and environmentalist groups in Chile. Moreover, regular activists who had not previously been involved in any particular organisation were interviewed in both countries. In the case of academics, I selected scholars who were studying topics such as social movements, social networks and the Internet.

An online survey was sent in both countries with the exact same questions, but in different languages. Both of them were intended to capture the opinion of people who had participated in the protests. In the UK, the survey was sent to undergraduate

6 Information according to www.internetworldstats.com, accessed on 15-08-2011. 
and postgraduate students through the University College London (UCL) Union online newsletter. The survey had 132 responses, most of them from postgraduate students $-56.8 \%$ - with ages ranging from 18 to 52 years and an average age of 26 . In the case of Chile, the survey was distributed through Twitter and Facebook and got 246 responses. As the protests in Chile were related to environmental policies, the population intended to be reached was broader than in case of the UK. The link of the survey was shared by highly influential Chilean Twitter users and by some NGOs, such as Greenpeace Chile. The average age of the Chilean respondents was 32 years old and most respondents were studying or had an undergraduate degree $-41.3 \%$.

Both surveys were intended to primarily cover a population of Internet users, avoiding any limitations caused by coverage error (Manfreda \& Vehovar, 2008). Nonetheless, as the surveys did not utilise any probabilistic sampling methods, it is not possible to make generalisations beyond the composition of the sample that participated in them. Nonetheless, online surveys do offer some significant advantages by comparison to other, similar instruments, such as telephone surveys. As Stephenson and Crete (2011) showed, online surveys are able to get straighter answers from respondents than telephone surveys, especially regarding complex topics such as participation in protests and other types of political demonstration.

Finally, data from the Oxford Internet Survey 2009 was used to provide further analysis on the findings about the perception of democracy. This survey aims to reach a nationally representative sample of 2000 people the population of Britain above 14 years old, using face-to-face interviews. The data was weighted according to the instructions provided by the Oxford Internet Institute. (Dutton, Helsper, \& Gerber, 2010)

\section{Hypotheses and findings}

According to the literature reviewed above (Norris, walgrave and Vang Aelst, 2005), protesters show higher levels of support for democracy than those who do not engage in demonstrations. One of the suggested explanations for this is that protesters are more engaged in the pursuit of higher levels of democracy and, concordantly, the main goal of the protests is to deepen democracy in their countries. In that sense, the use of the Internet during a protest may increase the level of support for democracy, as it provides better tools for the co-ordination of collective action (Hypothesis 1.1). Nonetheless, some would argue that the Internet has no effect at all on the level of support for democracy (Hypothesis 1.2). In this regard, people 
who engage in protests hold views about democracy as a system of government, as something completely unrelated to the way in which they decide to protest.

In the case of the concept of democracy, one argument is that the specific types of social ties formed through Internet tools such as Twitter or Facebook may foster more horizontal relations among users. Hence, when they start to use the Internet to participate in politics, they would repeat the horizontality learnt through the use of the Internet. Another view suggests that the Internet may not be changing the way that people relate to each other. Instead, what affects our view about democracy is the utopian ideal we possess about the Internet and not necessarily its alleged horizontal features. In that regard, the process by which people modify their conception of democracy would be the response of a performativity process in which the idealistic discourse of the Internet - and not the Internet itself - affects perceptions of democracy. Consequently, it would be necessary to analyse whether the Internet is changing the way that democracy is conceived, by creating a more horizontal conception of it (Hypothesis 2.1) or not (Hypothesis 2.2).

\section{Support for democracy}

Most interviewees agree that protests are an important - if not essential - part of modern democracy. It could be argued that protests are a way in which citizens are able to engage more directly and intensively with the democratic process, while it could also be asserted that people will support democracy regardless of whether they have a strong opinion about what democracy is. As one journalist from the UK explained, "they [the protesters] would definitively argue that this [the protest] is very democratic. I think they support their own view of democracy".

A Chilean journalist compared the act of protesting with that of voting, arguing "The protesters strengthen their support for democracy. I think that they feel that the ritual of protesting is very similar to the ritual of voting”. When directly asked whether the Internet has any particular effect on the level of support for democracy, only one of the interviewees - a journalist - stated that it does. In his words, "The Internet gives people access to a voice and a power they claim as democratic. I think it enhances the ideological idea of active engagement with society and the democratic process". Nonetheless, the majoritarian view lies on the side of the sceptics. This argument can be summarised in the words of one of the academics interviewed: "We are witnessing a '1.0' system of organisation [the protests] that uses a '2.0' way of communication, but is just that. There is no significant change'. 
In the case of the regression models, the dependant variable comes from a question in which the survey respondents were asked to choose - on a scale from 1 to 10 - how important it was for them to live in a democratic country. The first model used as an independent variable the different uses of the Internet during the protests (Table 1.1 and 1.2). This variable was coded from a multiple answer question, in which the respondents were asked to enumerate the different ways in which they used the Internet to engage in the protests - if any.

Table 1.1

Support for democracy, UK survey.

\begin{tabular}{|c|c|c|c|c|}
\hline $\begin{array}{l}\text { Dependent Variable: } \\
\text { Support for Democracy }\end{array}$ & Model 1 & Model 2 & Model 3 & Model 4 \\
\hline \multirow{2}{*}{$\begin{array}{l}\text { Use of the Internet } \\
\text { in Protests }\end{array}$} & & $0.210^{\star}$ & 0.351 & 0.294 \\
\hline & $(0.074)$ & $(0.092)$ & $(0.220)$ & $(0.200)$ \\
\hline Evaluation of democracy & & $\begin{array}{l}0.309+ \\
(0.161)\end{array}$ & $\begin{array}{l}0.312+ \\
(0.164)\end{array}$ & $\begin{array}{l}0.334^{\star} \\
(0.161)\end{array}$ \\
\hline $\begin{array}{l}\text { Participation in the Protests } \\
\text { (online and/or offline) }\end{array}$ & & & $\begin{array}{l}-0.147 \\
(0.168)\end{array}$ & $\begin{array}{l}-0.049 \\
(0.157)\end{array}$ \\
\hline Education & & & & $\begin{array}{c}-0.476+ \\
(0.267)\end{array}$ \\
\hline Gender & & & & $\begin{array}{c}0.109 \\
(0.286)\end{array}$ \\
\hline \multirow[t]{2}{*}{ Age } & & & & $0.086^{\star \star}$ \\
\hline & & & & $(0.033)$ \\
\hline Constant & $9.186 \star \star \star$ & $6.845 \star \star \star$ & $6.977 \star \star \star$ & $6.017 \star \star \star$ \\
\hline $\mathbf{N}$ & 79 & 79 & 79 & 79 \\
\hline r2 & 0.03 & 0.164 & 0.173 & 0.256 \\
\hline r2_a & 0.017 & 0.142 & 0.14 & 0.194 \\
\hline Legend: Standard errors in () & $+\mathrm{p}<0.10$ & $\star \mathrm{p}<0.05$ & $\star \star p<0.01$ & $\star \star \star \mathrm{p}<0.00$ \\
\hline
\end{tabular}


Table 1.2

Support for democracy, Chile survey

\begin{tabular}{|c|c|c|c|c|}
\hline $\begin{array}{l}\text { Dependent Variable: } \\
\text { Support for Democracy }\end{array}$ & Model 1 & Model 2 & Model 3 & Model 4 \\
\hline Use of the Internet in Protests & $\begin{array}{l}0.220^{\star \star} \\
(0.084)\end{array}$ & $\begin{array}{l}0.251^{\star} \\
(0.102)\end{array}$ & $\begin{array}{l}0.317+ \\
(0.154)\end{array}$ & $\begin{array}{l}0.321+ \\
(0.151)\end{array}$ \\
\hline Evaluation of democracy & & $\begin{array}{c}0.064 \\
(0.060)\end{array}$ & $\begin{array}{c}0.049 \\
(0.052)\end{array}$ & $\begin{array}{c}0.048 \\
(0.053)\end{array}$ \\
\hline $\begin{array}{l}\text { Participation in the Protests } \\
\text { (online and/or offline) }\end{array}$ & & & $\begin{array}{l}-0.113 \\
(0.121)\end{array}$ & $\begin{array}{l}-0.110 \\
(0.120)\end{array}$ \\
\hline Education & & & & $\begin{array}{c}0.148 \\
(0.168)\end{array}$ \\
\hline Gender & & & & $\begin{array}{c}0.104 \\
(0.204)\end{array}$ \\
\hline \multirow[t]{2}{*}{ Age } & & & & 0.014 \\
\hline & & & & $(0.016)$ \\
\hline Constant & $8.824 \star \star \star$ & $8.378 \star \star \star$ & $8.687 \star \star \star$ & $7.687 \star \star \star$ \\
\hline $\mathrm{N}$ & 121 & 121 & 121 & 121 \\
\hline r2 & 0.068 & 0.081 & 0.092 & 0.114 \\
\hline r2_a & 0.061 & 0.065 & 0.068 & 0.067 \\
\hline Legend: Standard errors in () & $+\mathrm{p}<0.10$ & $\star \mathrm{p}<0.05$ & $\star \star p<0.01$ & $\star \star \star p<0.001$ \\
\hline
\end{tabular}

This resulted in seven dummy variables, which were added to construct a single scale. The following multivariate model includes the respondents' evaluation of democracy in order to assess whether there is a relationship between both variables. The third model includes the last three variables plus a variable for participation in the protests. This variable was designed to assess if the respondent had participated in the protests, regardless of their involvement online. Finally, the fourth model includes basic demographic control variables, such as gender, education and age.

As Tables 1.1 and 1.2 show, the first model presents a significant positive relationship between the use of the Internet during the protests and the level of support for democracy in both countries. Nonetheless, the level of significance tends to drop as more variables are incorporated into the model. In both countries, the significance of the relationship between the use of the Internet in the protests and support for democracy looses significance in Model 3 - in the case of Chile, it remains significant at the $\mathrm{p}<0.10$ level, while in the UK it looses all significance. When the 
demographic variables are controlled for, education and age becomes important in the UK, while in Chile these do not make a significant difference.

The quantitative and qualitative data coincide in suggesting that the effect of the use of the Internet during the protests on the level of support for democracy might not be relevant. Moreover, the qualitative evidence strongly suggests that the relevant element in the relationship is participation in the protests, regardless of the Internet. In that sense, the protests may deepen the level of compromise with democracy among protesters by allowing them to exercise political activities in a more unstructured and recurrent way. Regarding this specific dimension, the Internet may serve as a mere tool for protesters. This evidence supports Hypothesis 1.2 in the sense that the Internet has no effect whatsoever on the level of support for democracy. Consequently, according to this data, Hypothesis 1.1 can be rejected on the basis that even when the survey data shows a positive relationship between the use of the Internet and support for democracy, the phenomenon seems to have a certain degree of spuriousness.

\section{The Conception of Democracy}

For the purpose of analysing this dimension, one of the survey questions asked respondents to offer a definition of democracy using their own words. This openended question was intended to allow respondents to express their views beyond the classical close-ended questions from the Barometer surveys. The answers were coded 1 if the respondents related democracy to attributes such as "horizontal", "equality of power", "inclusion of everyone" or other related ideas. If respondents clearly expressed their concept of democracy as institutions - elections, parliament, elected representatives, liberties, freedom of speech, personal liberty or social rights, education, health, and social care, and so on - the answers were coded as zero. With this binary dependent variable, bivariate and multivariate regression models were used. 
Table 2.1

Horizontal Democracy, UK survey

\begin{tabular}{|c|c|c|c|c|}
\hline Horizontal Democracy & Model 1 & Model 2 & Model 3 & Model 4 \\
\hline $\begin{array}{l}\text { Use of the Internet in } \\
\text { Protests }\end{array}$ & $\begin{array}{c}1.090 \star \star \star \\
(0.264)\end{array}$ & $\begin{array}{l}1.125 \star \star \star \\
(0.287)\end{array}$ & $\begin{array}{l}0.597 \\
(0.650)\end{array}$ & $\begin{array}{c}0.862 \\
(0.759)\end{array}$ \\
\hline Evaluation of democracy & & $\begin{array}{c}0.181 \\
(0.214)\end{array}$ & $\begin{array}{c}0.121 \\
(0.182)\end{array}$ & $\begin{array}{c}0.315 \\
(0.225)\end{array}$ \\
\hline $\begin{array}{l}\text { Participation in the Protests } \\
\text { (online and offline) }\end{array}$ & & & $\begin{array}{l}0.477 \\
(0.552)\end{array}$ & $\begin{array}{l}0.628 \\
(0.579)\end{array}$ \\
\hline Education & & & & $\begin{array}{c}0.058 \\
(0.722)\end{array}$ \\
\hline Gender & & & & $\begin{array}{l}-0.714 \\
(1.042)\end{array}$ \\
\hline \multirow[t]{2}{*}{ Age } & & & & $0.209 \star$ \\
\hline & & & & $(0.087)$ \\
\hline Constant & $-2.909 \star \star \star$ & $-4.312^{\star}$ & $-4.299 \star$ & $-11.952^{\star \star}$ \\
\hline $\mathbf{N}$ & 59 & 59 & 59 & 59 \\
\hline $\begin{array}{l}\text { Legend: Standard errors } \\
\text { in () }\end{array}$ & $+p<0.10$ & ${ }^{\star} \mathrm{p}<0.05$ & $\star \star p<0.01$ & $\star \star \star \mathrm{p}<0.001$ \\
\hline
\end{tabular}

Table 2.2

Horizontal Democracy, Chile survey

\begin{tabular}{|c|c|c|c|c|}
\hline Horizontal Democracy & Model 1 & Model 2 & Model 3 & Model 4 \\
\hline Use of the Internet in Protests & $\begin{array}{l}0.376^{\star} \\
(0.149)\end{array}$ & $\begin{array}{l}0.354^{\star} \\
(0.161)\end{array}$ & $\begin{array}{l}0.414^{\star} \\
(0.197)\end{array}$ & $\begin{array}{l}0.453^{\star} \\
(0.196)\end{array}$ \\
\hline Evaluation of democracy & & $\begin{array}{l}-0.039 \\
(0.095)\end{array}$ & $\begin{array}{l}-0.050 \\
(0.098)\end{array}$ & $\begin{array}{l}-0.054 \\
(0.108)\end{array}$ \\
\hline $\begin{array}{l}\text { Participation in the Protests } \\
\text { (online and offline) }\end{array}$ & & & $\begin{array}{l}-0.099 \\
(0.173)\end{array}$ & $\begin{array}{l}-0.093 \\
(0.182)\end{array}$ \\
\hline Education & & & & $\begin{array}{l}-0.290 \\
(0.284) \\
\end{array}$ \\
\hline Gender & & & & $\begin{array}{l}-0.928^{*} \\
(0.450)\end{array}$ \\
\hline \multirow[t]{2}{*}{ Age } & & & & 0.035 \\
\hline & & & & $(0.025)$ \\
\hline Constant & -1.648 & -1.363 & -1.118 & -1.034 \\
\hline $\mathbf{N}$ & 104 & 104 & 104 & 104 \\
\hline Legend: Standard errors in () & $+\mathrm{p}<0.10$ & $* \mathrm{p}<0.05$ & $* * \mathrm{p}<0.01$ & $\begin{array}{c}* * * \\
\mathrm{p}<0.001\end{array}$ \\
\hline
\end{tabular}


Tables 2.1 and 2.2 show that there is a statistically significant positive relation between the use of the Internet during the protests and the appearance of the horizontal concept of democracy. The most interesting feature of this relation is that in the case of Chile, it holds in all of the different models. The only other variable that has statistical significance in the Chilean models is gender: men tend to think of democracy as being horizontal more frequently than women. In the case of the UK, the relation between the use of the Internet and the horizontal concept of democracy is significant only in the first two models. Nonetheless, there is an important caveat to be made in this case. As the question used to create the dependent variable was open-ended, respondents were allowed to leave it blank. This led to a considerable drop in the sample size from the previous models.

Despite this caveat, there is a positive relation between the two variables and that none of the other variables - except for gender in the Chilean case - appeared to have a significant relation. One of the possible causes of this could be that there is a genuine effect explained by the use of the Internet, which in turn would mean that $\mathrm{H} 2.2$ could be rejected.

The interview data confirms the existence of this relationship and provides more information about the possible underlying mechanisms. In the first place, as explained above, the Internet serves as a new tool for protesters and activists to access the mainstream media. This means that the content published in newspapers and showed on TV is increasingly coming from the users of online social networks. Mainstream journalists are learning to get their information straight from Twitter or Facebook and, hence, there is a more direct flow of information between protesters and the media. In this regard, one of the interviewed academics explained that most of the alleged influence of social media derives from a buzz generated by the mainstream media. Traditional journalists may thus be over-reacting to the emergence of new media and its capabilities during periods of contentious political action.

Another plausible explanation is that the Internet is fostering a less hierarchical organisational structure among protesters. As one of the activists from the UK student protests explained, they used the Internet to create a consensual way of decision-making: "We decided everything by consensus, by raising our hands. We also used people's opinion from Twitter or the blog during the meetings". On a related note, a UK journalist argued, "these new tools allow them to do this [the organisation of the protests] a lot easier, but I think that this way of operation belongs to a different form of democracy, to a new way to see it". 
There is a third argument that could help explain the relation between the use of the Internet and the horizontal view of democracy. According to this perspective, the Internet is fostering "democracy 2.0", in which ordinary citizens can participate as equals with politicians and other elites in the political process. As one of the Chilean academics explained, "users have limitless options to generate content, they can say what they want for the first time. You don't have to 'eat whatever they sell you'". One journalist interviewed went even deeper by stating that through the Internet "I'm no longer voting only once every several years. Now I vote and decide everyday, through social media, blogs or other tools". Some of the interviewees even compared the Internet to the romantic idea of the Greek polis, one claiming, "Twitter is becoming the new public square of democracy 2.0, in which everyone can shout a message". Most of those who attribute these features to the Internet also argue that this new way of political participation is changing our perception of democracy from a more traditional - or representative - conception to a more horizontal - or direct - one.

Nevertheless, there is no consensus on this horizontal conception of the Internet. One of the academics explained, "on the Internet we are all equals, but there are some who are more equal than others, just as in Orwell's Animal Farm". This argument relates to the idea that on Twitter, not everyone has the same influence, which is based on the number of followers and mentions a user has. "There is no equality on Twitter, there are those who have thousands of followers and their voice is more influential than the large majority of users", noted a Chilean academic. One of the interviewed activists claimed that kids from poor backgrounds still lack sufficient access to the Internet. In his words,

"In the UK, everyone should have access to the Internet, that's what I believe to be democracy: that everyone can access information and can debate and share it in equal terms with anyone else".

In the Chilean case, this concern is even more pronounced. An interviewed activist explained that:

"As long as we keep our access differences, the democratising potential of the Internet is severely restricted. The risk is that we may fall under the illusion of false participation when, in reality, we may be fostering the creation of a new elite, the elite of the connected". 
The evidence is strong in suggestions that the Internet may not actually have the idealistic democratising power that some attribute to it. Nonetheless, this does not affect the fact that the Internet is in some sense creating a new conception of democracy. This idea relates democracy to horizontal values such as equality, inclusion and equal participation in the decision-making process. From the evidence gathered in this investigation, it is possible to suggest - not without extreme caution - a possible causal link between the use of the Internet in the protests - or at least with the alleged democratic discourse of it - and this new conception of democracy. Hence, H2.1 could be supported.

In order to test the idea that some sort of utopian discourse about the Internet might be responsible for this link, data from the OxIS 2009 has been used. This survey contained a question about the level of agreement with the statement that "through the use of the Internet, people like you can have more political power". This question provides a good proxy to analyse that discourse among respondents. As discussed above, the idea that the Internet creates an environment in which all people have access to power is common among certain groups. In addition, following Dalton's (2008) notion of "engaged citizenship", the OxIS survey asks respondents about their participation in a list of political activities. According to Dalton, some - such as contacting a politician, donating money to civic organisations, or participating in a protest - are more common among people who understand citizenship more as an engagement than a duty. The same type of people hold views such as equal treatment of citizens by government, better protection of minority rights, and higher support for civil disobedience (Dalton, 2008:128). These attitudes are very similar to those reflecting horizontal ideas about democracy, and therefore, can be used to observe the predicted presence of utopian discourse of the Internet.

Table 3.3 shows different logistic regressions using the participation in several political activities that can be labelled as "non-institutional" and that reflect what Dalton considered "engaged citizenship". There are two constructed dependent variables: one binary that accounts for any type of participation in these activities, and other that creates a scale form 0 to 6 , depending on the amount of activities that a respondent declared. All the models are weighted according to the instructions provided by the Oxford Internet Institute.

The idea that Internet provides more political power affects positively the likelihood of participating in non-institutional activities overall, and is particularly significant 
in the case of contacting a politician, ethical consuming, and donating to a civic organisation.

These results are also preliminary evidence in support for the idea that the Internet carries a utopian discourse, and also that this discourse might be affecting the way in which people participate and, consequently, how do people conceptualise democracy. Obviously, this evidence is not conclusive. More analyses are required in the measurement of the conceptions of democracy, and for the purposes of this article, no similar data is available from Chile at the moment. 


\begin{tabular}{|c|c|c|c|c|c|c|c|c|}
\hline 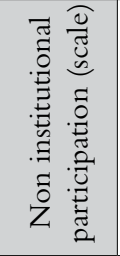 & 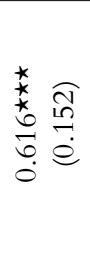 & 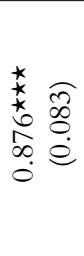 & 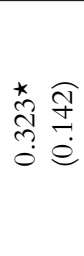 & 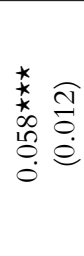 & 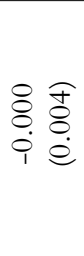 & & $\begin{array}{l}3 \\
=\end{array}$ & \\
\hline 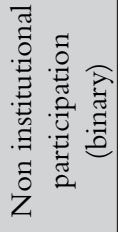 & 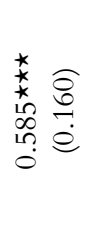 & $\begin{array}{ll}* & \\
k & \widehat{E} \\
* & \infty \\
\dddot{0} & 0 \\
0 & 0 \\
0 & 0\end{array}$ & 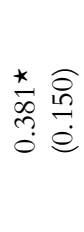 & 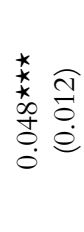 & 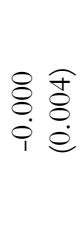 & 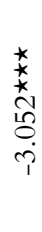 & $\stackrel{\infty}{=}$ & \\
\hline 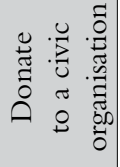 & 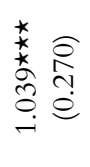 & 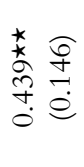 & $\begin{array}{l}\Re \\
\stackrel{\infty}{0} \\
\stackrel{+}{0} \\
\stackrel{0}{0}\end{array}$ & 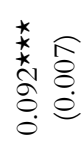 & 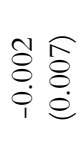 & 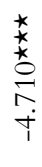 & $\stackrel{ \pm}{\stackrel{ \pm}{\Xi}}$ & \\
\hline 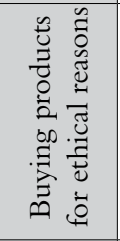 & 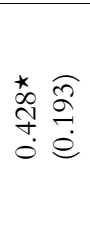 & 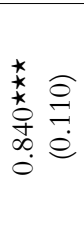 & 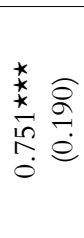 & $\begin{array}{ll}\frac{*}{3} & \widehat{n} \\
0 & 0 \\
0 & 0 \\
0 & 0\end{array}$ & $\begin{array}{l}\bar{\delta} \stackrel{\Omega}{8} \\
\dot{8} \\
\dot{0}\end{array}$ & 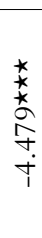 & $\stackrel{ }{\equiv}$ & \\
\hline 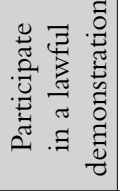 & 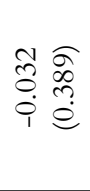 & 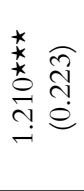 & $\begin{array}{l}\text { iv } 0 \\
\text { ñ } \\
\stackrel{n}{e} \\
i=\end{array}$ & 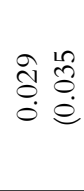 & 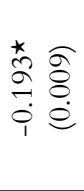 & 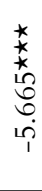 & 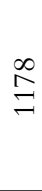 & \\
\hline 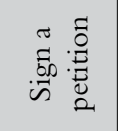 & $\begin{array}{l}\overparen{\overbrace{}} \\
\stackrel{\overbrace{}}{f} \\
\stackrel{?}{e}\end{array}$ & $\begin{array}{ll}* & \\
* & \infty \\
k & \infty \\
\cdots & 0 \\
0 & 0 \\
0 & 0 \\
0 & 0\end{array}$ & 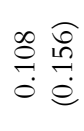 & 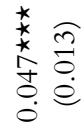 & 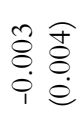 & 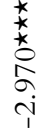 & $\stackrel{શ}{\beth}$ & $\begin{array}{ll} & \overline{8} \\
* & 0 \\
* & \dot{8} \\
2 & \end{array}$ \\
\hline 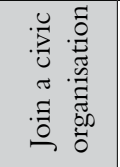 & 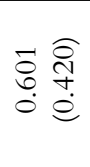 & 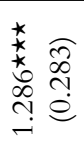 & 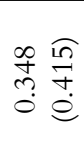 & 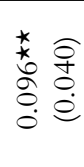 & 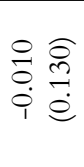 & 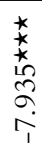 & $\stackrel{?}{\stackrel{ }{=}}$ & $\begin{array}{l}\overrightarrow{0} \\
\dot{0} \\
\mathrm{v} \\
2 \\
+ \\
*\end{array}$ \\
\hline 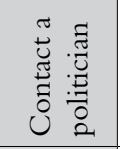 & 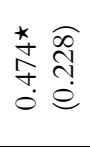 & 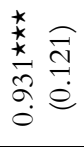 & 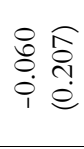 & 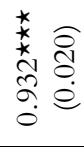 & 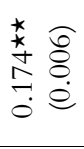 & 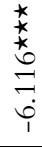 & $\stackrel{ }{\equiv}$ & $\begin{array}{l}\stackrel{n}{0} \\
\dot{0} \\
\stackrel{v}{2} \\
\text { * }\end{array}$ \\
\hline & 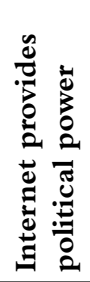 & 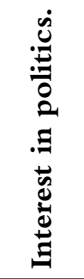 & 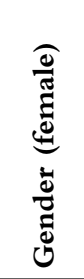 & : & $\underset{4}{\infty}$ & 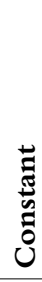 & $\mathbf{Z}$ & 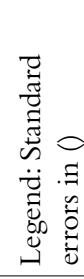 \\
\hline
\end{tabular}




\section{Conclusions}

One of the main questions in the research field of online politics is whether or not the Internet is changing the way we behave politically. In the case of the present investigation, that question is narrowed to analyse the effect of the Internet on perceptions of democracy. From the evidence gathered, the answer to this question is "yes, to a certain degree". In the case of support for democracy, it appears that the "Axiological Rationality" model (Sarsfield \& Echegaray, 2006) holds. Protesters tend to support democracy regardless of their evaluation of it, the medium by which they demonstrate or even their level of involvement with a social movement. Support for democracy comes from deeper beliefs and the Internet appears to have no significant effect on them.

Understanding of the concept of democracy proves to be more complex. The evidence suggests that the Internet is responsible for a change in the way that protesters understand democracy. This is a bold statement, but the complexity increases with inquiry into whether the Internet actually affects the concept of democracy, or is mere utopian discourse on it. From what I have researched, it is not possible to give a definitive answer to this question. However, the data is inclined to the more sceptical side of the spectrum. Internet activists are confronted with the contradiction of promoting the hypothetical horizontal credentials of the Internet, while at the same time recognising that it is fostering the creation of the same types of elites as in the offline world. Moreover, there is a general recognition of a persistent digital divide. It is interesting that the utopian discourse of the Internet and not the Internet itself - may be creating a performativity effect; a self-fulfilled promise of the democratic potential of the Internet. The question will remain unanswered until more research is done, although the available data clearly points somewhat in this direction.

\section{Bibliography}

Bennett, L., Breunig, C., \& Givens, T. (2008). "Communication and Political Mobilization: Digital Media and the Organization of Anti-Iraq War Demonstrations in the U.S." Political Communication, vol 25, n³, pp. 269-289.

Cantijoch, M. (2008). "The Influence of the Internet on different types of political participation in Spain". Presented at the ECPR Graduate Conference, Barcelona.

Dalton, R.J. (2008). The good citizen: how a younger generation is reshaping American politics. CQ Press. 
Dalton, R., Shin, D., \& Jou, W. (2008). How People Understand Democracy. How People View Democracy. Baltimore: Johns Hopkins University Press.

Di Gennaro, C., \& Dutton, W. (2006). "The Internet and the public: Online and offline political participation in the United Kingdom." Parliamentary Affairs, vol 59, $\mathrm{n}^{\circ} 2$.

Diamond, L. (2008). How People View Democracy. Baltimore: Johns Hopkins University Press.

Dutton, W., Helsper, E., \& Gerber, M. (2010). OxIS 2009 Report: The Internet in Britain. OxIS Reports. Oxford: Oxford Internet Institute. Retrieved from http://www.oii. ox.ac.uk/research/oxis/OxIS2009_Report.pdf

Garret, K. (2006). "Protest in an Information Society: a review of literature on social movements and new ICTs." Information, Communication and Society, vol 9, n², pp.202224.

Gerring, J. (2004). "What Is a Case Study and What Is It Good For?" American Political Science Review, vol 48, n², pp, 341-354. doi:10.1017/S0003055404001182

Gerring,J. (2007). Case study research : principles and practices. NewYork: Cambridge University Press.

Lagos, M. (2008). Latin America's Diversity of Views. How People View Democracy. Baltimore: Johns Hopkins University Press.

Manfreda, K., \&Vehovar,V. (2008). Internet Surveys. International Handbook of Survey Methodology, European Association of Methodology. Sussex, England: Psychology Press.

McAdam, D., Tarrow, S., \& Tilly, C. (2001). Dynamics of Contention.

Morozov, E. (2011). The Net Delusion: How not to liberate the world. ePenguin.

Norris, P., Walgrave, S., \& Van Aelst, P. (2005). "Who demonstrates? Antistate rebels, conventional participants, or everyone?" Comparative politics, vol 37, n²2, pp. 189-205.

Sarsfield, R., \& Echegaray, F. (2006). "Opening the black box: How satisfaction with democracy and its perceived efficacy affect regime preference in Latin America." International Journal of Public Opinion Research, vol 18, n², pp. 153-173.

Stephenson, L. B., \& Crête,J. (2011). "Studying Political Behavior:A Comparison of Internet and Telephone Surveys." International Journal of Public Opinion Research, vol 23, nº1, pp 24 - 55.

Tarrow, S. (2008). Power in Movement: Social Movements and Contentious Politics. Cambridge studies in comparative politics. Cambridge: Cambridge University Press.

Tilly, C., \& Tarrow, S. (2007). Contentious politics. Paradigm Publishers. 
Van Laer, J. (2007). Internet Use and Protest Participation: How do ICTs affect mobilization? Universiteit Antwerpen, Faculteit Politieke en Sociale Wetenschappen.

Van Laer, J., \& Van Aelst, P. (2009). "Cyber-protest and civil society: the Internet and action repertoires in social movements." jewkes, y majid, y (editor), Handbook on Internet Crime.

Welzel, C., \& Inglehart, R. (2008). The Roles od Ordinary People in Democratization. How People View Democracy. Baltimore: Johns Hopkins University Press.

Yin, D. R. K. (2008). Case Study Research: Design and Methods. Sage Publications, Inc. 
